\title{
DURANTA REPENS LINN. (VERBENACEAE): A COMPREHENSIVE REVIEW OF PHARMACOGNOSTIC, ETHNOMEDICINAL, PHARMACOLOGICAL, AND PHYTOCHEMICAL ASPECTS
}

\author{
ABHIJEET V PURI* \\ Department of Pharmacognosy, St. John Institute of Pharmacy and Research Vevoor, Palghar, Maharashtra, India. \\ Email: avpuri@rediffmail.com/abhijeetp@sjipr.in
}

Received: 14 July 2018, Revised and Accepted: 14 August 2018

\section{ABSTRACT}

Objective: This review is intended to investigate the published report regarding phytochemical, ethnomedicinal, and pharmacological activities and put forth the therapeutic potential of Duranta repens Linn. (D. repens). It belongs to the family Verbenaceae, one of the therapeutically important plants, broadly distributed all throughout the world. It is commonly referred as golden dewdrop, angel whisper, pigeon berry, or skyflower.

Methods: I utilized logical writing and scientific literature regarding D. repens by referring search engine such as Springerlink, ScienceDirect, SciFinder, PubMed, Scopus, Google Scholar, and BioMed Central as well as relevant books, websites, scientific publications, and dissertations as a source of information that provided an up-to-date review. My work on morphology and extraction of various phytochemicals and their evaluation has helped to provide an insightful account of $D$. repens.

Results: Phytochemical profiling of these species revealed the presence of some imperative phytochemicals such as alkaloids, flavonoids, glycosides, phenolics, saponins, steroids, tannins and terpenoids as the basis of its valuable therapeutic properties. The other imperative phytoconstituents which contribute to the therapeutic properties are durantol, repennoside, repenins, and scutellarein. The pharmacological activities exhibited by $D$. repens as antimicrobial, antioxidant, and insecticide properties are attributed to the presence of valuable bioactive phytoconstituents.

Conclusion: Considering these facts, I endeavored to present a comprehensive review enlightening the phytochemistry and pharmacological activities of plant $D$. repens. Future research can be directed to an extensive investigation about phytochemistry, clinical trials, pharmacokinetics, and acquiring safety data so as to add new dimensions to the therapeutic utilization of D. repens and other Duranta species.

Keywords: Duranta repens, Verbenaceae, Microscopical characters, Phytochemicals.

(c) 2018 The Authors. Published by Innovare Academic Sciences Pvt Ltd. This is an open access article under the CC BY license (http://creativecommons. org/licenses/by/4. 0/) DOI: http://dx.doi.org/10.22159/ajpcr.2018.v11i12.28509

\section{INTRODUCTION}

Duranta repens Linn. (D. repens) belonging to family Verbenaceae is native to clean and open forests. It is used as an ornamental plant in tropical nations [1,2]. The genus Duranta was described by Linnaeus (1753). This genus is named after Castor Durante (1529-1590), a French physician and botanist [3]. The plants of Verbenaceae family are herbs, shrubs, or trees comprising about 100 genera and 2,600 species. Around 35 Duranta species with evergreen bushes are spread over tropical and subtropical areas. D. repens was used in Egypt as an ornamental plant [4]. D. repens (Golden dewdrop) otherwise called sky blossom, angels-whisper, additionally called Katamehedi. Duranta is an upright to hanging bush that occasionally takes the type of a scrambling bush or once in a while a little tree $[5,6]$. They mostly occur in tropical and subtropical and few temperate regions. Habit varies from tree lianas to shrubs and herbs. Leaves are simple, opposite or alternate arranged, entire or divided, and exstipulate. Flowers are often involucres of colored bracts. Plants are sometimes thorny. Fruits are fleshy drupes, usually 8-seeded, completely enclosed by the persistent calyx. Fruits are less commonly capsular or schizocarps. Seeds show a presence of oily embryo with little or absence of endosperm. The economic uses include as sources of timbers, essential oils, teas, herbal medicines, fruits, gums, tannins, and ornamentals. Flowers are small mostly blue-purple, or white bracteates with racemes are either terminal or axillary. Calyx tube subcampanulates ribbed and toothed. Corolla tube is cylindrical straight or apically curved and pubescent at the mouth. An Ovary is 4-carpelled with 8 locules, one ovule in each lobule, style terminal with unequally 4 -lobed stigma $[7,8]$.

\author{
Introduction to $D$. repens \\ Taxonomical classification $[9,10]$ \\ Domain: Eukaryota \\ Kingdom: Plantae \\ Subkingdom: Tracheobionta (Vascular plants) \\ Phylum: Spermatophyta \\ Subphylum: Angiospermae \\ Class: Dicotyledonous \\ Subclass: Asteridae \\ Order: Lamiales \\ Family: Verbenaceae (the Vervain family) \\ Genus: Duranta \\ Species: Duranta repens \\ Common Name: Golden Dewdrop
}

Vernacular names[11]

English: Golden dewdrop, pigeonberry, and skyflower

Kannada: Neelakantha

Marathi: Piwali Mendi

French: Vanillier de Cayenne

Indonesian: Sinyo nakal

Japanese: Taiwan-rengyô

Tongan: Mavaetangi

Vietnamese: Thanhquan

South Africa: Geelbessi 


\section{GEOGRAPHIC DISTRIBUTION OF D. REPENS}

Golden dewdrop grows wild mostly in a dry coastal area from near sea level to over $100 \mathrm{~m}$ in elevation. It grows in areas with moister habitat, and especially, along roads. Golden dewdrop is native to Mexico, Central America, South America Argentina, Southern Florida (possibly naturalized), Bermuda, the Bahamas, and the West Indies. The species is widely cultivated in tropical and subtropical regions which includes Hawaii, American Samoa, and Guam. It is extensively cultivated throughout India along the sides of rivers and banks of streams. It grows on rocky slopes and mostly found sometimes along roadsides in villages [12-16]. Golden dewdrop forms a part of the coastal scrub community and contributes to soil and ecosystem stability. It is a commonly grown plant when trimmed forms a strong, compact hedge which is almost impenetrable to cattle. It is a popular ornamental plant used as an accent and planted in tropical and subtropical parts of the world because of its profuse displays of flowers [17].

\section{TRADITIONAL USES OF D. REPENS}

Traditional plants are an important source of a natural remedies and remain to be broadly used to treat many diseases [18]. An infusion of the leaf and juice of the fruit is diuretic, and flower is said to have stimulant properties. Both leaf and fruit give a positive test for hydrocyanic acid. In the Chinese system of medicine, fruits are mentioned as poisonous berries. The plant is claimed to treat malaria which still stands as a major disease in the developing countries. Water-macerated fruits yield a juice which even in dilutions of 1:100 parts of water are lethal to mosquito larvae; the action is less marked on culicine larvae. The juice can be used as a larvicidal in ponds and swamps. Fruit contains an alkaloid analogous to narcotine while leaf contains saponins. Some glycosides are also reported from the bark of the plant. In Chinese medicine, the fruits were used for the treatment of malaria, and the leaves are employed for the treatment of abscesses [19]. The fruit is said to cause illness and death in children. The symptoms imply sleepiness, high temperature, dilated pupil, rapid pubes, swelling lips and eyelids, and convulsions [20]. The seeds yield oil with the following characteristics: Acid value (58.62\%), saponification value (210.9), iodine value (101.3), and unsaponifiable matter $(0.4 \%)$ [21]. The plant is believed to be poisoning the livestock and is said to be very bitter hence not eaten by livestock [22]

\section{CHARACTERISTICS OF THE PLANT D. REPENS}

The shrub grows up to a $7 \mathrm{~m}$ with branches subquadrangular, drooping or trailing, spiny, and sparsely pubescent and turns glabrous with age. Terminal inflorescence is axillary with $10-30 \mathrm{~cm}$ long and racemed with many flowers. It is usually erect recurved with $3-10 \mathrm{~cm}$ long pubescent. A peduncle of the flower is $5-15 \mathrm{~mm}$ longer in size. Flowers have a fragrance with minute bracts. They are linear 1-4 mm long with lower ones occasionally subfoliaceous exceeding the calyx. The pedicel is $1-5 \mathrm{~mm}$ long and pubescent shown in Fig. 1.

Calyx is long 3-7 mm tubular glabrescent with appressed pubescent or canescent outside. It is glabrous inside with 5-angled tube and 5 -min teeth at the rim. The base is triangular, and the apex is subulate about 0.5-1 mm long. Corolla is light bluish-purple or white in color. It is puberulous outside, pubescent inside, often glandular with tube 6-10 $\mathrm{mm}$ long and $1.5-2 \mathrm{~mm}$ diameter. Stamens inserted above the middle of the corolla-tube are filaments with $0.5-1.5 \mathrm{~mm}$ long and appear with few hairs. Anthers are oblong and $\pm 1 \mathrm{~mm}$ long. Ovary is subglobose glabrous with style $2-3 \mathrm{~mm}$ long stigma is minutely capitate and 4-lobed. Fruit is orange-yellow with subglobose or obpyriform and glabrous completely enclosed by the accrescent orange-yellow shiny calyx. Macroscopical characters of the leaves as shown in Fig. 2 demonstrate a dark green color on both surfaces seen as deciduous; leaf base is decurrent symmetrical petiolated.

The composition of the lamina is simple, pinnate reticulate venation, entire margin, acuminate apex, sub-ribs alternate, surface glabrous, and texture subcoriaceous. The size of leaves varies from 1.5 to $4.6 \mathrm{~cm}$ in length and $2.4 \mathrm{~cm}$ in breath [23]. D. repens shows several stems or drooping spiny branches, especially when carrying a large number of fruit. The bark is light gray, becoming rough, and fissured when old. There are usually at least some pairs of spines along the stems, one located at the base of each of the leaf stalks [24].

\section{BIOLOGICAL AND PHARMACOLOGICAL ACTIVITIES}

Natural products have been playing a substantial part throughout the world in treating and averting human diseases [25]. Literature proposes that $D$. repens $L$. has been accounted for a wide variety of medicinal activities. The whole plant is used in the treatment of infertility, pneumonia, and malaria, as diuretic, itches, anthelmintic, neuralgic disorders and also as an insect repellent. D. repens also exhibits activities such as anti-shigellosis, cytotoxic potency, antiviral activity, antioxidant, antibacterial, and antimicrobial against human pathogens [24-29] (Table 1).

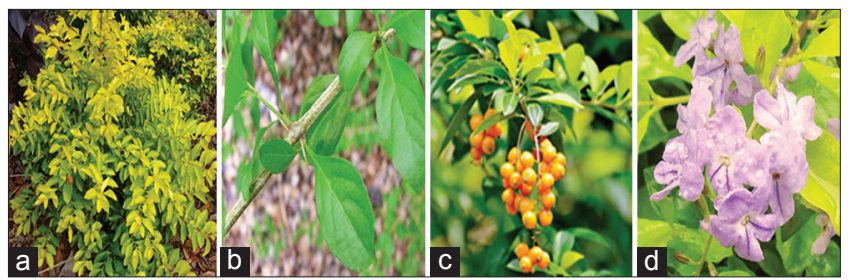

Fig 1: Morphology of the D. repens Linn. Plant. (a) Plant of

$D$. repens L. (b) Stem of $D$. repens L. c) Fruits of $D$. repens $\mathrm{L}$. (d) Flower of $D$. repens $\mathrm{L}$.

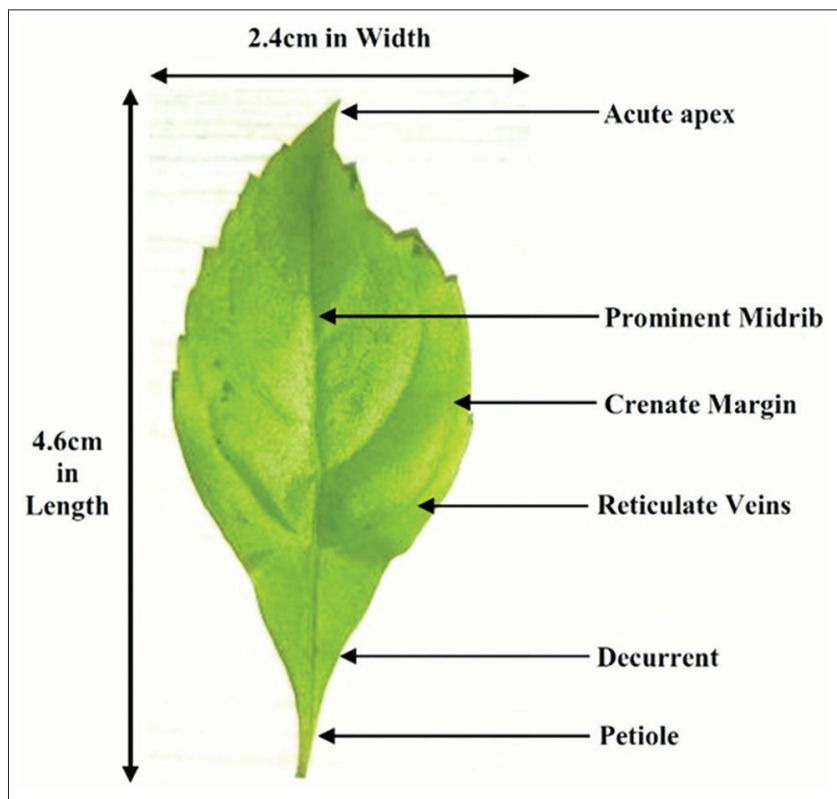

Fig. 2: Macroscopical characteristics of Duranta repens Linn. leaf

Table 1: Biological activities of $D$. repenes

\begin{tabular}{lll}
\hline Sr. No & Activity reported & Reference \\
\hline 1 & Thrombin inhibitory & {$[30,31]$} \\
2 & Mosquitocidal & {$[41]$} \\
3 & Antiviral & {$[33]$} \\
4 & Cytotoxicity & {$[32]$} \\
5 & Antioxidant & {$[45-47]$} \\
6 & Antiplasmodial & {$[39]$} \\
7 & Anti-shigellosis & {$[34]$} \\
8 & Antifungal & {$[37,38]$} \\
9 & Antimicrobial & {$[34-36]$} \\
10 & Insecticidal Property & {$[42-44]$} \\
\hline
\end{tabular}

D. repenes: Duranta repenes 


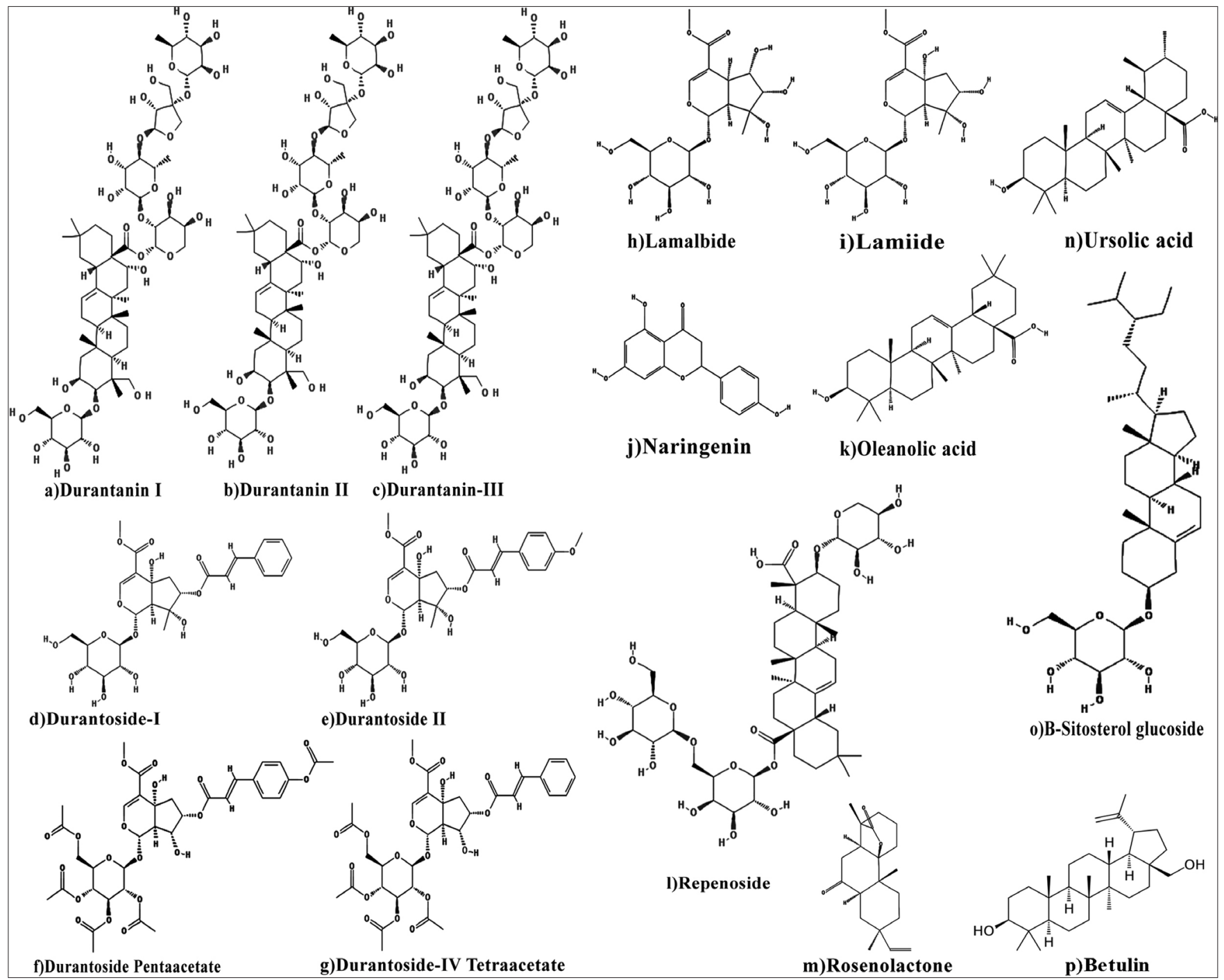

Fig. 3: Phytoconstituents of $D$. Repenes Linn.

\section{Thrombin Inhibitory Activity}

Anis et al. reported isolation and evaluation of isoprenylated flavonoids, tri-methoxyflavone, isoprenylated acetophenone, and other derivatives for thrombin inhibitory activity. Results concluded inhibitory activity against propyl endopeptidase active against thrombin [30]. Anis et al. isolated C-alkylated flavonoids, trans-clerodane diterpenoids, and other constituents from D. repens. The known flavonoid was reported for the first time from this species. This flavonoids showed significant thrombin inhibitory activity [31]

\section{Cytotoxic activity}

Ahmed et al. isolated two new triterpene saponins and ten known compounds and screened for cytotoxic activity on brine shrimps. The investigated methanol extract and compounds, durantin, known as compound 2 and 7 showed significant cytotoxic activity against a HepG2 cell line [32].

\section{Antiviral activity}

Abou-Setta et al. reported antiviral activity of the ethanolic extract of D. repens against hepatitis A virus. Results showed $76 \%$ reduction in viral titer of hepatitis A with ethanolic extract at the concentration of $40 \mu \mathrm{g} / \mathrm{mL}$, while at $20 \mu \mathrm{g} / \mathrm{mL}$, the inhibition reached $64 \%$ determined by plaque reduction assay. The methanolic extract showed $88 \%$ inhibition at the concentration of $40 \mu \mathrm{g} / \mathrm{mL}$, while at $20 \mu \mathrm{g} / \mathrm{mL}$, the inhibition reached $59 \%$ of the virus by the same assay. They suggested that this antiviral activity may be attributed to the acetosides or lamiide content of the extract [33].

\section{Antimicrobial activity}

Nikkon et al. reported extraction, fractionation, and isolation of two triterpenes ( $\beta$-Amyrin and 12-Oleanene) from the chloroform-soluble fraction of an ethanolic extract and also determined minimum inhibitory concentrations (MIC) of the ethanolic extract of D. repens stem, which were evaluated for antibacterial and antifungal activities by the disc diffusion method and cytotoxicity by brine shrimp lethality bioassay. The MICs of the extracts (stem and fruits), their fractions, and compound 1 were found to be in the range of 32 128 $\mu \mathrm{g} / \mathrm{ml}$ [34]. Ogbuagu et al. evaluated the antibacterial activity of methanolic extract obtained from Nigerian $D$. repenes leaves against some human pathogenic bacteria: Proteus mirabilis, Bacillus subtilis, Salmonella typhi, and Boletus aereus at $75,150,300$, and $600 \mathrm{mg} / \mathrm{mL}$ by the agar diffusion method. The result of MIC determined showed significant activities against the growth of P. mirabilis, B. subtilis (141 $\mathrm{mg} / \mathrm{mL})$, S. typhi $(81 \mathrm{mg} / \mathrm{mL})$, and B. aereus $(100 \mathrm{mg} / \mathrm{mL})$ [35]. Jayalakshmi et al. reported the antibacterial activity of various solvent extracts of medicinal plants against the human pathogenic bacteria such as Escherichia coli, Klebsiella pneumoniae, B. subtilis, Bacillus cereus, S. typhi, E. aerogenes, and S. aureus by agar cup diffusion method. Methanol extracts of $D$. repens $\mathrm{L}$. showed significant antibacterial activity. The antibacterial activity of plant extract is promising as compared to standard drugs streptomycin and gentamicin [36]. 
Antifungal activity

Sharma et al. reported the antifungal properties of the methanolic extract of different parts such as leaves, stem, and roots of $D$. repenes against Aspergillus niger, Aspergillus flavus, Aspergillus umigatus, and Penicillium sp. using agar disc diffusion method. They reported that methanolic extract of leaf and stem of $D$. repenes was effective against A. niger, A. flavus, and A. fumigatus at $1000 \mathrm{mg} / \mathrm{mL}$ concentration which recorded significant inhibition zone of $2.3 \mathrm{~cm}$, $2.3 \mathrm{~cm}$, and $2.2 \mathrm{~cm}$, respectively [37]. Sikarwar et al. investigated the antifungal activity of aqueous and methanolic leaf extracts of $D$. repens against three fungi $A$. niger, C. albicans, and M. gypseum by disc diffusion method. The result showed promising antifungal activity against the tested fungi. Antifungal activity of the test extracts at different inhibitory concentration varied significantly $(0.05$ level of significance). Where methanolic extract proved to be effective compared to the aqueous one [38].

\section{Antiparasitic activity}

Ijaz et al. reported that $D$. repens from Pakistan showed antiplasmodial activity against the chloroquine-sensitive and chloroquine-resistant strains of Plasmodium falciparum, with $\mathrm{IC}_{50}$ values of $8.5 \pm 0.9$ and $10.2 \pm 1.5 \mu \mathrm{g} / \mathrm{mL}$, respectively [39].

\section{Insecticidal property}

El-Naggar and Mosallam evaluated that extracts from D. repens had antifeedant and insecticidal properties against the larvae of Culex pipiens and Spodoptera littoralis and the adults of Musca domestica [40]. Nikkon et al. reported larvicidal activity of crude extracts from the stem and fruits, and their fractions and fresh fruit juice of D. repens were assayed against the larvae of Culex quinquefasciatus. The highest larval mortality was found in chloroform-soluble fraction of the stem, with $12 \mathrm{~h}-\mathrm{LC}_{50}$ being $10.75 \mathrm{ppm}$, and in ethanolic extract of fruits, with $12 \mathrm{~h}-\mathrm{LC}_{50}$ being $8.51 \mathrm{ppm}$ against the first instar larvae. Various concentrations of fresh fruit juice showed potent effects on C. quinquefasciatus, and the larvae showed proportional tolerance with the increase of their age and time. These results suggest that the stem and fruits of $D$. repens are very effective natural larvicidal and can be useful against Culex quinquefasciatus [41]. McConnell et al. evaluated insecticidal property of the methanol and water extracts of $D$. repens Linn. leaves against larvae of $C$. quinquefascitatus (Say). Here, both the extracts of $D$. erecta have larvicidal activity [42]. Hemavathy et al. reported larvicidal activity of the aqueous and methanolic extracts of $D$. repens leaves from India against larvae of $C$. quinquefasciatus that showed the high percentage of mortality compared to ethanolic extract. At $10 \%$ concentration of the extract of water, methanol, and ethanol, the larvae found to be dead were 17, 16, and 13 of 20 larvae [43]. Roy et al. evaluated an aqueous extract of D. repens from India against the teared spider mite (Oligonychus coffeae) to determine its effect on adult mortality, the viability of eggs, oviposition deterrence, and repellent properties. The direct spray method was used at concentrations of 2, 4, 6, 8, and $10 \mathrm{~g} / \mathrm{L}$. Deposition of eggs by adult mites on treated leaf surfaces decreased, and the viability of eggs was also reduced. Its efficacy was comparable to that of the commonly used commercial neem oil azadirachtin formulation. In addition, in the field, the application of the aqueous extract of $D$. repens reduced the mite population, and its efficacy was comparable to that of the synthetic pesticide propagate [44].

\section{Antioxidant activity}

Ahmad et al. reported phytochemical investigations on the chloroformsoluble fraction of the whole plant of $D$. repens Linn. They isolated four new coumarinolignoids: Repenins, coumarinolignoids, cleomiscosin, and durantin. The compounds showed significant radical scavenging activity against 2,2-diphenyl-1-picryl-hydrazyl-hydrate (DPPH) radicals, with $\mathrm{IC}_{50}$ values in the range $0.420-0.625 \mathrm{mM}$. Repenin displayed the strongest scavenging potential with $\mathrm{IC}_{50}$ values of $0.420 \mathrm{mM}$ [45]. Shahat et al. isolated three compounds from methanol extract of $D$. repens from Egypt, i.e., phenylethanoid glycoside, acetosides, iridoid lamiide, and saponin pseudo-ginsenoside-RT1. Acetosides showed an
$\mathrm{IC}_{50}$ of $3.05 \pm 0.09 \mu \mathrm{g} / \mathrm{mL}$ in the DPPH assay, while lamiide and pseudoginsenoside-RT1 were not active [46]. Khan et al. investigated ethanol and methanol extracts of $D$. repens fruits for the antioxidative potential that can protect $\mathrm{H}_{2} \mathrm{O}_{2}$-induced oxidative cell damage. HEK293T cells were treated with different concentrations $(0-1000 \mu \mathrm{g} / \mathrm{ml})$ of ethanol extract and methanol extract of $D$. repens for $24 \mathrm{~h}$ and then treated with $100 \mu \mathrm{M} \mathrm{H}_{2} \mathrm{O}_{2}$ for $24 \mathrm{~h}$. They determined cell viability and antioxidant constituent of the extracts. Treatment with a limited dose of both extracts increased the survival rate of $\mathrm{H}_{2} \mathrm{O}_{2}$-treated HEK293T cells; however, the extra-high dose showed growth inhibitory effect. The results showed treatment with both extracts protected cellular lipid peroxidation. In vitro analysis showed that ethanol and methanol extracts increased the survival rate of $\mathrm{H}_{2} \mathrm{O}_{2}$-treated HEK293T cells, lipid peroxidation, 2, 2-diphenyl-1-picrylhydrazyl, and $\mathrm{H}_{2} \mathrm{O}_{2}$ scavenging activities. A limited dose of ethanol and methanol extracts possesses antioxidative potential, which can protect $\mathrm{H}_{2} \mathrm{O}_{2}$-induced oxidative cell damage [47].

\section{Phytochemical composition}

Literature proposes that $D$. repens $\mathrm{L}$. contains a wide array of various bioactive compounds. Interestingly almost all parts of the D. repens species have been exploited for phytochemical investigation, and various phytoconstituents are isolated till date. Various important phytoconstituents have been reported such as C-alkylated flavonoids, steroids, flavonoids, terpenoids, triterpenes, beta-sitosterol, naringenin, triterpenes saponins, steroidal glycosides, and glycosides as shown in Fig. 3. From Duranta genus, several iridoid glycosides as durantosides are isolated. The leaves contain a saponin, and fruits contain alkaloid analogous to narcotine [48]. Itrat et al. 2001 reported the two C-alkylated flavonoids, two C-tropane type of triterpenes, and flavonoid as 3,5,4'trihydroxy-6,7-dimethoxyflavone [49]. Ahmed et al. from the chloroform fraction of D. repens isolated 24-ethy125-hydroxychol-esta-4,22(23)-dien-3-one steroid [50]. Harbome et al. reported a 5,6,7-trihydroxy-4'- methoxy-flavone [51]. Kuo et al. described a new iridoid, durantoside-IV pentaacetate from the leaves of $D$. repens. The same authors, working on the leaves of this plant, recently reported oleanolic and ursolic acids and from the hexane extract $\beta$-sitosterol glucosides. From the acetone extract, they have also reported inorganic salts from the water-soluble portion of ethanolic extract and E-cinnamic acid, and (E)-p-methoxycinnamic acid and a fraction containing a strongly bitter substance were isolated from the ethyl acetate soluble fraction of the ethanolic extract. The fraction containing bitter substances was later found to comprise of glucose pentaacetate, kusaginin non-acetate, and verbascoside [52-56]. Hiradate et al. reported three triterpenoid saponins, durantanin-I, II, and III, respectively, from the leaves of D. repens which are the plant growth inhibitors. Durantoside-I pentaacetate, durantoside-I tetraacetate, durantoside-II tetraacetate, durantoside-IV pentaacetate, and durantoside- $\mathrm{V}$ tetraacetate were also isolated from D. repens $[57,58]$. Rimpler and Timm reported the presence of three iridoid glucosides as durantoside-I, II, and III [59]. Rao et al. reported durantoside-IV [60]. Other constituents reported were (+)-Hardwickiic acid [61], (+)-3,13-Clerodadien-16,15-olid-18-oic acid[62], betulin[63], stigmasterol[64], stigmasterol 3-0-,8-D-glucopyranoside [65], andscutellarein and pectolinarigenin [66].

\section{CONCLUSION}

Based on the existing review of literature, D. repens reveals its valuable therapeutic use as antimicrobial, antifungal, antiviral, and antimalarial and in other parasite infestation. It has a potent free radical scavenging activity which sufficiently demonstrated in different experimental and clinical studies. Its potential as an antioxidant and cytoprotective agent needs to be undermined in future research work. Various unique molecules of $D$. repens can also be chemically modified or used as "lead" for developing more effective drug molecules. Therefore, extensive pharmacological and phytochemical analysis, experimentations, together with pharmacokinetic and toxicological studies will be a focus for 
forthcoming investigation. Furthermore, a well-designed study to measure its toxicity from its long-term use is another urgency. This review article emphasizes the potential of $D$. repens that can be employed in new therapeutic drugs and will offer the base for future research on the application of herbal medicines.

\section{AUTHORS' CONTRIBUTION}

Abhijeet Puri: Concept of paper, compiling full literature, the inscription of a manuscript, revising, the read-through of the manuscript, and contributed to improve the standard of the manuscript.

\section{CONFLICTS OF INTEREST}

The authors declare that he has no conflicts of interest.

\section{REFERENCES}

1. Ganapaty S, Jaya BG, Naidu KC. Phytochemical studies of roots of D. repens. Indian J Nat Prod 1997;13:11-4

2. Hiradate S, Yada H, Ishii T, Nakajima N, Ohnishi-Kameyama M, Sugie $\mathrm{H}$, et al. Three plant growth inhibiting saponins from $D$. repens. Phytochemistry 1999;52:1223-28.

3. Munir AA. A taxonomic revision of the genus Duranta L. (Verbenaceae) in Australia. J Adel Bot Gard 1995;16:1-16.

4. Bircher WH. Gardens of Hesperides. Cairo: The Anglo-Egyptian Book Shop; 1960. p. 70-660

5. Liogier HA. Descriptive Flora of Puerto Rico and Adjacent Islands. San Juan, and PR: Editorial de la Universidad de Puerto Rico; 1995. p. 617.

6. Little EL, Woodbury Jr RO, Wadsworth FH. Trees of Puerto Rico and the Virgin Islands. Agriculture Handbook, 449. Washington DC; U.S: Department of Agriculture; 1974. p. 1024.

7. Nasir E, Ali SI. Flora of West Pakistan. Karachi: Department of Botany, University of Karachi; 1974. p. 18-9.

8. Ray $\mathrm{AB}$, Gupta M. Withasteroids -a growing group of naturally occurring steroidal lactones. Prog Chem Org Nat Prod 1994;63:1-106.

9. Taxonomical Classification of Duranta repens Linn. In Flowers of India. Available from: https://www.anjanadesigns.blogspot. com/2017/05/flowering-plants-of-kerala-golden-dew.html. [Last accessed on 2018 Apr 20]

10. Taxonomical Classification of Duranta repens Linn. Invasive Species Compendium. Available from: https://www.cabi.org/isc/ datasheet/20192. [Last accessed on 2018 Apr 20].

11. Vernacular Names of Duranta repens Linn. Medicinal Plants with Usage, Patents and Their Publications. Available from: http://www. medplants.blogspot.com/2017/03/duranta-erecta-golden-dewdrop. html. [Last accessed on 2018 Apr 20].

12. Hardin JW, Arena JM. Human Poisoning from Native and Cultivated Plants. Durham NC; Duke University Press; 1969. p. 67.

13. Howard RA. Flora of the Lesser Antilles. Arnold Arboretum. Jamaica: Harvard University; 1989. p. 658.

14. Pacific Island Ecosystems at Risk. 2002. Duranta erecta L, Verbenaceae. Available from: http://www.hear.org/pier3/duere.htm. [Last accessed on 2018 Apr 20].

15. Srivastav PK, Tayal MK. Virtuous Plants. $1^{\text {st }}$ ed. Delhi: Scientific Publishers; 2017. p. 89.

16. Asolkar LV, Kakkar KK, Chakre OJ. Second Supplement to Glossary of Indian Medicinal Plants with Active Principles Part-I. New Delhi: National Institute of Science Communication (CSIR); 1992. p. 264.

17. Sastri BN. The Wealth of India. New Delhi, India: Publication and Information Directorate CSIR;1952. p. 117-9.

18. Badgujar N, Mistry K, Patel J. V. Negundo, L. Camara and B. Variegata plants leaf extract exhibit considerable in vitro antioxidant and anticancer activities. Int J Pharm Pharm Sci 2017;9:227-32.

19. Peigeng X. A Pictorial Encyclopaedia of Chinese Medical Herbs. Tokyo: Chuokoron Sha, Inc.; 1992. p. 158

20. Watt JM, Brandwijk MG. The Medicinal and Poisonous Plants of Southern and Eastern Africa. $2^{\text {nd }}$ ed. London, United Kingdom: E. and S. Livingstone; 1962. p. 149

21. The Wealth of India. Raw materials. Vol III. New Delhi: 13-E Council of Scientific and Industrial Research; 1952. p. 128.

22. Perry LM, Metzger J. Medicinal Plants of East and Southeast Asia. Cambridge, England: The MIT press; 1980. p. 432

23. Puri AV, Ansari YN, Puri PA. Pharmacognostic, physicochemical and phytochemical investigation of leaves of $D$. repens Linn. Res J Pharm Phytochem 2017;9:141-6.
24. Said RM. Response of sky flower (Duranta erecta L. var. Variegata) transplants as pot-plant to growing media and water amounts. Middle East J Agric Res 2016;5:201-7.

25. Acharya N, Barai P, Katariya H, Acharya S, Santani D. Evaluation of antidiabetic potential of roots and stems of G. arborea. Int J Pharm Pharm Sci 2015;7:355-62.

26. Castro O, Barrios M, Chinchilla M, Guerrero O. Evaluacion quimica y biologica delefecto de extractos de plant as contra Plasmodium berghei. Revista de Biologia Tropical 1996;44:361-7.

27. Rahmatullah M, Jahan R, Azam FM, Hossan S, Mollik MA. Folk medicinal uses of Verbenaceae family plants in Bangladesh. Afr J Tradit Complement Altern Med 2011;8:53-65.

28. Bangou MJ, Méda NT, Thiombiano AM, Kiendrebéogo M, Zeba B, Millogo-Rasolodimby J, et al. Antioxidant and antibacterial activities of five Verbenaceae species from Burkina Faso. Curr Res J Biol Sci 2012;6:665-72

29. Prabhakar G, Kamalakar P, Ashok VT, Shailaja K. In-vitro screening of antibacterial activity of seeds of Crotalaria verrucosa L. and Duranta erecta L. Eur J Pharm Med Res 2015;2:411-19.

30. Anis I, Ahmed S, Malik A, Yasin A, Choudhary MI. Enzyme inhibitory constituents from Duranta repens. Chem Pharm Bull 2002;50:515-18.

31. Anis I, Anis E, Ahmed S, Mustafa G, Malik A, Amtul Z, et al. Thrombin inhibitory constituents from $D$. repens. Helv Chim Acta 2001;84:649-55

32. Ahmed WS, Mohamed MA, El-Dib RA, Hammed MM. New triterpene saponins from $D$. repens Linn. And their cytotoxic activity. Molecules 2009;14:1952-65.

33. Abou-Setta LM, Nazif NM, Shahat AA. Phytochemical investigation and antiviral activity of D. repens. J Appl Sci Res 2007;3:1426-33

34. Nikkon F, Habib MR, Karim MR, Hossain MS, Mosaddik MA, Haque ME. Antishigellosis and cytotoxic potency of crude extracts and isolated constituents from D. repens. Mycobiology 2008;36:173-7

35. Ogbuagu AS, Okoro K, Akpuaka MU, Ogbuagu JO, Ekpunobi UE, Ohaekenyem EC. Quantitative determination of some secondary metabolites and the anti-bacterial effects of the leave extracts of Duranta eracta. Am J Biomed Sci Eng 2015;1:82-7.

36. Jayalakshmi B, Raveesha KA, Amruthesh KN. Phytochemical investigations and antibacterial activity of some medicinal plants against pathogenic bacteria. J Appl Pharm Sci 2011;1:124-8

37. Sharma P, Khandelwal S, Singh T, Vijayvergia R. Phytochemical analysis and antifungal potential of Duranta erecta against some phytopathogenic fungi. Int J Pharm Sci Res 2012;3:2686-9.

38. Sikarwar M, Ganie SA, Agnihotri RK, Sharma R. Evaluation of $D$. repens for its antifungal potential. Int J Med Plants 2014;106:390-5.

39. Ijaz F, Ahmad N, Ahmad I, ul Haq A, Wang F. Two new anti-plasmodial flavonoid glycosides from $D$. repens. J Enzyme Inhib Med Chem 2010;25:773-8

40. El-Naggar ME, Mosallam SS. Insecticidal properties of some isolates from D. repens L. J Egypt Soc Parasitol 1987;17:243-9.

41. Nikkon F, Saud ZA, Hossain K, Parvin MS, Haque ME. Larvicidal effects of stem and fruits of $D$. repens against the mosquito Culex quinquefasciatus. Int J Pharm Tech Res 2009;1:1709-13.

42. McConnell MS, Balasubramani M, Rajan K, Gerald IA. Evaluation of the larvicidal activity of the leaf extracts of Duranta erecta Linn. (Verbenaceae) on the larvae of Culex quinquefascitatus (Say) (Culicidae). J Biopest 2010;3:582-5.

43. Hemavathy J, Anitha T. A study on larvicidal assay on D. repens Linn. and Vitex negundo Linn. against Culex quinquefasciatus say. Int J Adv Sci Res 2016;1:18-20.

44. Roy S, Muraleedharan N, Handique G, Rahman A, Barua A. Aqueous extracts of $D$. repens (Verbenaceae) as an alternative to control tea red spider mite, Oligonychus coffeae (Acari: Tetranychidae). Int J Trop Insect Sci 2016;36:82-90.

45. Nisar A, Fozia Z, Ahmad I, Wang F. Repenins A-D four new antioxidative coumarinolignoids from $D$. repens Linn. Bioorg Med Chem Lett 2009;19:3521-4.

46. Shahat AA, Nazif NM, Abousetta LM, Ibrahim NA, Cos P, Van Miert S, et al. Phytochemical investigation and antioxidant activity of $D$. repens. Phytother Res 2005;19:1071-3

47. Khan MA, Rahman MM, Tania M, Shoshee NF, Xu AH, Chen HC. Antioxidative potential of $D$. repens (Linn.) fruits against $\mathrm{H}_{2} \mathrm{O}_{2}$ induced cell death in vitro. Afr J Tradit Complement Altern Med 2013;10:436-1.

48. Khare CP. Indian Medicinal Plants: An Illustrated Dictionary. Berlin: Springer-Verlag; 2007. p. 227.

49. Ahmed S, Nizami TA, Nawaz HR, Malik A. A new steroid from Duranta repens. Fitoterapia 1998:L212:448-50. 
50. Harborne JB, Valdes B. Identification of scutellarein 40-methyl ether in Linaria aeruginea. Phytochemistry 1971;10:2850.

51. Kuo YH, Kubota T. The structure of durantoside IV tetra-acetate. Experientia 1976;32:968-9.

52. Lee SM, Lai JS, Kuo YH. Constituents of Clinopodium Umbrosum. J Chin Chem Soc 1993;40:87-91.

53. Kuo YH, Shue MJ. New esters, 2-(4-hydroxy-3-methoxyphenyl) ethyl hexa and octacosanoates from the leaves of Cinnamomum Reticulatum Hay. J Chin Chem Soc 1991;38:65-9.

54. Kuo YH, Chen ZS, Lin YL. Chemical components of the leaves of Duranta repens Linn. Chem Pharm Bull 1996;44:429-6.

55. Yoshio T, Youko M, Takashi M, Choei O, Eiji H, Anki T. et al. Iridoid glucosides from the leaves and stems of Duranta erectal L. Phytochemistry 1995;39:829-3.

56. Hiradate S, Yada H, Ishii T, Nakajima N, Ohnishi-kameyama M, Sugie H, et al. Three plant growth inhibiting saponins from Duranta repens $\mathrm{L}$. Phytochemistry 1999;52:1223-8.

57. Lin YL, Kuo YH. A new glycoside brachynoside isolated from Clerodendron brachyanthum. Chem Pharm Bull 1992;40:1928-9.

58. Rimpler H, Timm H. Iridoids and ecdysones from verbenaceae iridoids from Duranta repens L. Z. Naturforsch 1974;29:111-5.

59. Rao CB, Rao TN, Kumar VE, Vijay EK. Chemical examination of the fruits of Duranta plumeri Jacq. Indian J Chem 1978;16:844-5.

60. Templeton W. An Introduction of the Chemistry of the Terpenoids and Steroids. London: Butterworth; 1969. p. 104

61. Robert MC, Patricia LC. Stereochemistry of the enzymic cyclization of copalyl pyrophosphate to kaurene in enzyme preparations from Marah macrocarpus. J Am Chem Soc 1980;102:6358-9.

62. Arnoldi A, Arnone A, Merlini L. Synthesis of the natural coumarinolignoids propacin and cleomiscosin and $\mathrm{b}$ an empirical spectroscopic method to distinguish region isomers of natural benzodioxane lignoids. Heterocycles 1984;22:1537-44

63. Ray AB, Chattopadhyay SK. Structure of cleomiscosin B, a coumarino lignoid of Cleome viscosa Seeds. Heterocycles 1982;19:19-22.

64. Kumar S, Ray AB, Konno C, Oshima Y, Hikino H. Cleomiscosin D a coumarino-lignan from seeds of Cleome viscosa. Phytochemistry 1988;27:636-8.

65. Salama OM, Amer MM, Lahloub MF, Spengel S. Repennoside a new iridiod glucoside from Duranta repens Fruits. J Pharm Sci 1992;8:212-21

66. Subramanian SS, Nair AG. Scutellarein and pectolinarigenin from the leaves of Clerodenron phlomides and Duranta repens L. Phytochemistry 1972;11:3095-6. 